\title{
Contribution of microbial and invertebrate communities to leaf litter colonization in a Mediterranean stream
}

\author{
A. Gaudes ${ }^{1}$ \\ Departament d'Ecologia, Facultat de Biologia, Universitat de Barcelona, Av. Diagonal 645, \\ E-08028 Barcelona, Spain
}

\begin{abstract}
J. Artigas ${ }^{2}$, A. M. Romaní ${ }^{3}$, AND S. Sabater ${ }^{4}$
Institut d'Ecologia Aquàtica i Dept. Ciències Ambientals, Facultat de Ciències, Universitat de Girona, Campus Montilivi, E-17071 Girona, Spain
\end{abstract}

I. $\mathrm{Muñoz}^{5}$

Departament d'Ecologia, Facultat de Biologia, Universitat de Barcelona, Av. Diagonal 645, E-08028 Barcelona, Spain

\begin{abstract}
Leaf litter inputs and retention play an important role in ecosystem functioning in forested streams. We examined colonization of leaves by microbes (bacteria, fungi, and protozoa) and fauna in Fuirosos, an intermittent forested Mediterranean stream. Black poplar (Populus nigra) and plane (Platanus acerifolia) leaf packs were placed in the stream for 4 mo. We measured the biomasses and calculated the densities of bacteria, fungi, protozoa, meiofauna, and macroinvertebrates to determine their dynamics and potential interactions throughout the colonization process. Colonization was strongly correlated with hydrological variability (defined mainly by water temperature and discharge). The $1^{\text {st }}$ week of colonization was characterized by hydrological stability and warm water temperatures, and allocation of $\mathrm{C}$ from microbial to invertebrate compartments on the leaf packs was rapid. Clumps of fine particulate organic matter (FPOM) were retained by the leaf packs, and enhanced rapid colonization by microfauna and meiofaunal collector-gatherers (ostracods and copepods). After $2 \mathrm{wk}$, an autumnal flood caused a 20-fold increase in water flow. Higher discharge and lower water temperature caused FPOM-related fauna to drift away from the packs and modified the subsequent colonization sequence. Fungi showed the highest biomass, with similar values to those recorded at the beginning of the experiment. After $70 \mathrm{~d}$ of postflood colonization, fungi decreased to nearly $40 \%$ of the total $C$ in the leaf packs, whereas invertebrates became more abundant and accounted for $60 \%$ of the C. Natural flood occurrence in Mediterranean streams could be a key factor in the colonization and processing of organic matter.
\end{abstract}

Key words: Mediterranean stream, meiofauna, protozoa, bacteria, fungi, macroinvertebrates, C budget.

Leaf litter is an important energy source for food webs in forested stream ecosystems (Fisher and Likens 1973, Webster and Benfield 1986), especially in loworder systems (Minshall et al. 1985). Input and retention of organic matter in Mediterranean forested

\footnotetext{
${ }^{1}$ E-mail addresses: agaudes@ub.edu

2 joan.artigas@udg.es

3 anna.romani@udg.es

${ }^{4}$ sergi.sabater@udg.es

5 imunoz@ub.edu
}

streams are strongly affected by climate (Sabater et al. 2001, Acuña et al. 2005) because the annual peak of leaf fall often coincides with heavy flooding in autumn (Acuña et al. 2007, Gasith and Resh 1999). Thus, colonization and decomposition of leaf litter might be determined by the availability of organic matter and hydrology in Mediterranean forested streams (Gasith and Resh 1999). Floods are a major organizing factor of organic matter dynamics because they determine cycles of accumulation and removal. Consequently, they provoke changes in consumer communities. 
Leaf structure and chemistry and streamwater chemistry are the main determinants of microbial colonization and metabolism (Bärlocher et al. 1995, Gulis and Suberkropp 2003). Fungi are the main colonizers during initial phases, whereas bacteria dominate during late stages (Baldy et al. 1995) and probably benefit from fungus-induced changes in leaf surfaces or from the release of labile compounds (Allan 1995). The dominant role of fungi during colonization of large particulate organic matter (Gessner 1997, Findlay et al. 2002) and their contribution to overall loss of C from leaves (Hieber and Gessner 2002, Gulis and Suberkropp 2003, Pascoal and Cassio 2004) mean that net $C$ transformation mostly reflects the capacity of the fungal community to metabolize leaf matter.

The shredding activity of macroinvertebrates on decaying leaves contributes to the breakdown process. Shredders feed on coarse particulate organic matter and can accelerate decomposition by increasing leaf tissue fragmentation (Graça 2001, Graça and Canhoto 2006). Macroinvertebrates feed preferentially on conditioned leaves, thereby ingesting nutrients from leaf tissue and from the attached microbial community (Slansky and Scriber 1985). However, little information is available on the contribution of protozoa and smaller invertebrates to colonization and decomposition (Franco et al. 1998, Robertson and Milner 2001). Micro- and meiofauna are mostly bacterial specialists (Meyer 1994, Borchardt and Bott 1995), and they can exert significant grazing pressure on bacteria and fungi that colonize detritus (Perlmutter and Meyer 1991). Given the interaction between distinct groups of consumers, leaf litter breakdown is not a simple linear cause-and-effect relationship, but a simultaneous complex interaction between groups that could lead to several outcomes (Gessner et al. 1999).

We examined the complex interaction between decomposers and detritivores with regard to colonization of organic matter. We analyzed the successional colonization dynamics of microbes (including bacteria, fungi, and protozoa) and meio- and macrofauna on decaying leaves during a leaf-pack experiment in a forested Mediterranean stream. We addressed the following: 1) the most important factors that affect colonization dynamics, 2) the settlement sequence of leaf litter colonizers, and 3) the contribution of microbial organisms and meio- and macrofauna to the leaf litter biofilm and to the total $C$ budget of the leaf packs. We hypothesized that the sequence of colonization would occur in the order: microbes, meiofauna, and macrofauna. If this hypothesis is correct, $\mathrm{C}$ allocation should change between compartments over time. We also speculated that co-occurrence of organic matter processing and high climatic instability could introduce disruptions or accelerations into this sequence in Mediterranean streams.

\section{Methods}

\section{Study site}

We worked in an intermittent $3^{\text {rd }}$-order stream (Fuirosos) in northeastern Spain (lat $41^{\circ} 42^{\prime} \mathrm{N}$, long $\left.2^{\circ} 34^{\prime} \mathrm{W}\right)$. Fuirosos drains a $10.9-\mathrm{km}^{2}$ forested catchment that lies in the Natural Park of the MontnegreCorredor range. Precipitation occurs mostly in autumn and spring, which are periods of frequent flooding, with occasional storms in summer. High variation in rainfall is characteristic of this typical Mediterranean system, which has large deviations in mean monthly precipitation and considerable interannual differences. The stream usually has a mean discharge of $30 \mathrm{~L} / \mathrm{s}$, width of 3 to $4 \mathrm{~m}$, and depths ranging from 0.1 to $0.5 \mathrm{~m}$ (see details in Acuña et al. 2005).

We did the colonization study in a 50-m-long reach. The nearby riparian area (10-15-m width) formed a closed canopy from May to October. Dominant vegetation was alder (Alnus glutinosa L.), black poplar (Populus nigra L.), hazelnut (Corylus avellana L.), and plane (Platanus acerifolia Aiton-Willd.). Direct and lateral inputs of organic material (OM) ranged from 0.1 to $4.45 \mathrm{~g} \mathrm{C} \mathrm{m}^{-2} \mathrm{~d}^{-1}$ (Acuña et al. 2007). The canopy reduced incident light in summer, and total light increased in winter (Romaní et al. 2004).

\section{Sampling strategy}

We used the litter bag technique to monitor the microbial and faunal colonization of leaf litter. We collected recently abscised leaves of $P$. acerifolia and Populus nigra from the riparian floor in September 2003. We dried the leaves (room temperature, $48 \mathrm{~h}$ ) and sterilized them in an autoclave $\left(121^{\circ} \mathrm{C}, 30 \mathrm{~min}\right)$ before placing them in plastic mesh bags (1-mm mesh). The sterilization procedure can affect processing rates (Godshalk and Wetzel 1978), but we used it to eliminate previous colonizers. We used the relatively small mesh to facilitate analysis of the $C$ pathway throughout the biofilm where the microbial loop occurs and to prevent ingestion of the leaf tissue by larger external macroinvertebrates. We placed 11 thin ropes supporting 3 bags each (a total of 33 bags, each containing 4 Platanus and 6 Populus leaves) every 3 to 5 $\mathrm{m}$ (depending on the presence of natural leaf accumulation zones) along the 50-m reach. We retrieved 3 randomly selected bags on days $1,2,4,7,17,28,44,58$, 73, 93 and 112. Day 0 was 6 October 2003 when litter bags were immersed.

We reduced the loss of nonattached micro- and 
meiofauna from the leaf packs during retrieval by placing the still-immersed bags in a plastic container, which was then removed from the stream. We removed macroscopic colonizers from the outside of the bags if they were present. We took a leaf subsample and its surrounding water from the container and counted attached and nonattached protozoa. We used a metal borer to cut $1.1-\mathrm{cm}-$ diameter disks from the leaves and biofilm to sample fungi and bacteria. We placed samples for measurement of ergosterol (to estimate fungal biomass) in plastic vials and froze them $\left(-20^{\circ} \mathrm{C}\right)$ until analysis. We preserved samples for bacterial density in formalin $(2 \%)$. We dried additional leaf disks $\left(70^{\circ} \mathrm{C}\right)$ to constant mass to obtain dry mass (DM). We passed the rest of the contents of the mesh bag through $500-\mu \mathrm{m}$ and 32$\mu \mathrm{m}$ nested sieves. We scraped the leaf fraction retained by the $500-\mu \mathrm{m}$ sieve to detach macroinvertebrates and stored the leaves for later measurement of surface area with a scanner and ImageJ software (v. 1.40; http:// rsbweb.nih.gov/ij/index.html), biomass, and C content. We fixed macroinvertebrates retained in the 500$\mu \mathrm{m}$ sieve immediately in $4 \%$ formalin, and stored them for further counting and identification. We retained the fraction between the $500-\mu \mathrm{m}$ and $32-\mu \mathrm{m}$ sieves and stored it at $4^{\circ} \mathrm{C}$ for counting live meiofauna.

\section{Physicochemical measurements}

We measured $\mathrm{O}_{2}, \mathrm{pH}$, conductivity, and temperature with handheld meters (MultiLine F/SET-3; WTW, Weilheim, Germany) in the field on each sampling date. We measured current velocity (MiniAir2; Schiltknecht, Zurich, Switzerland) beside the litter bags before they were collected. We calculated stream discharge by using the slug-injection method with $\mathrm{NaCl}$ as the tracer (Gordon et al. 1992).

\section{Bacterial density and biomass}

We estimated bacterial density in triplicate in each litter bag after sonicating the samples $(2+2 \mathrm{~min}, 40-\mathrm{W}$ power, $40-\mathrm{kHz}$ frequency; Ultrasons, Selecta, Abrera, Spain). After appropriate dilution, we stained fixed samples for $5 \mathrm{~min}$ with 4',6-diamidino-2-phenylindole (final concentration $2 \mu \mathrm{g} / \mathrm{mL}$ ) and passed them through $0.2-\mu \mathrm{m}$ irgalan black-stained polycarbonate filters (Nuclepore; Whatman, Maidstone, UK). We counted bacteria in 15 fields/filter (400-800 organisms) with a fluorescence microscope (Eclipse E-600; Nikon, Tokyo, Japan) at $1250 \times$ magnification. We measured the volume of cells with a Soft Imaging System (analySIS ; Olympus, Münster, Germany). We used empirical bacterial biovolumes of $0.147 \mu \mathrm{m}^{3}$ (Populus) and $0.163 \mu \mathrm{m}^{3}$ (Platanus) and a conversion factor of $2.2 \times 10^{-13} \mathrm{~g} \mathrm{C} / \mu \mathrm{m}^{3}$ to estimate bacterial C (Bratbak and Dundas 1984).

\section{Ergosterol content}

We lyophilized frozen leaf samples and used 3 subsamples from each litter bag for ergosterol extraction by saponification with methanol $\left(80^{\circ} \mathrm{C}, 60 \mathrm{~min}\right)$ in a shaking bath. We purified the resulting extracts by solid-phase extraction (Gessner and Schmitt 1996) and measured ergosterol by high-performance liquid chromatography (Waters, Milford, Massachusetts). We detected ergosterol at $282 \mathrm{~nm}$ and quantified it by comparison with ergosterol standards $(0-200 \mu \mathrm{g} / \mathrm{mL}$; Fluka Chemical Co., Milwaulkee, Wisconsin) (Gessner and Schmitt 1996). We estimated fungal $C$ biomass on the basis of an ergosterol content of $5.5 \mathrm{mg} / \mathrm{g}$ fungal biomass (Gessner and Chauvet 1993) and 43\% C content in fungal dry mass (Baldy and Gessner 1997).

\section{Determination of microfauna, meiofauna, and macroinvertebrates}

We counted live microfauna (protozoan) samples on the day of collection with a microscope at $400 \times$ magnification (Polivar; Reichert-Jung, Wien, Austria). Meiofauna were counted within the next $2 \mathrm{~d}$ (occasionally $3 \mathrm{~d}$ ) under a dissecting microscope (MZ9.5; Leica, Wetzlar, Germany). Community composition and density of meiofauna in live samples were similar regardless of whether they were processed within 1 or $3 \mathrm{~d}$ (data not shown).

We determined microfaunal densities from counts in ten $100-\mu \mathrm{L}$ drops from each litter bag subsample. We also examined leaf tissue in the subsamples under a microscope to observe sessile ciliates. We identified individuals to order and assigned them to feedingtype groups (after Fenchel 1986, 1987, Franco et al. 1998): upstream filter feeders (UFF; with a ciliary upstream-collecting mechanism capable of capturing particles $>2 \mu \mathrm{m}$ ), downstream filter feeders (DFF; with an opposed band or downstream-collecting mechanism capable of capturing particles $<2 \mu \mathrm{m}$ ), and raptorial feeders (RF; with immobilization mechanisms, such as extrusomes). We estimated wet mass with values reported by Foissner and Berger (1996), and converted wet mass to $C$ biomass with published power equations (Bottrell et al. 1976).

We identified and measured soft-bodied meiofauna live, but we counted, identified, and preserved hardbodied meiofauna in formalin for further length and width measurements. We estimated biomass from exponential equations when they were available, or otherwise from biovolumes. We found published power equations or values for Ephemeroptera, Ple- 
coptera, Coleoptera, Diptera (Meyer 1989, Benke et al. 1999), Rotifera (Bott and Borchardt 1999), Copepoda, and Cladocera (Bottrell et al. 1976). We used biovolume estimates for Nematoda (after Andrassy 1956), Oligochaeta (Smit et al. 1993), Ostracoda, Hydracarina, Tardigrada, and Microturbellaria (Ramsay et al. 1997). We sorted fixed macroinvertebrates with a dissecting microscope, dried them $\left(70^{\circ} \mathrm{C}\right)$ to a constant mass, and burned them $\left(450^{\circ} \mathrm{C}, 4 \mathrm{~h}\right)$ to obtain biomass as ash-free dry mass. We expressed all densities (meiofauna and macroinvertebrates) per microgram of leaf DM. However, we obtained biomass (micrograms of organism C) through standard conversions (Waters 1977) and expressed it per microgram of leaf C in each litter bag.

\section{Data analyses}

We used nonparametric Spearman's rank coefficient to identify possible correlations between environmental and biological variables. We applied a false discovery rate correction (FDR; Benjamini and Hochberg 1995) because of the large number of comparisons made. We did these statistical analyses with STATISTICA (version 8.0; StatSoft, Tulsa, Oklahoma). We used ANOSIM on $4^{\text {th }}$-root $(x)$-transformed data to compare average ranked Bray-Curtis similarities among sampling dates with average ranked similarities within a sampling date (between replicates). We quantified dissimilarity between community assemblages through the colonization period with similarity percentages (SIMPER). We did these analyses with PRIMER (version 6.1.6; PRIMER-E, Plymouth, UK).

\section{Results}

\section{Physicochemical}

Water temperature decreased throughout the study period. It ranged from $\sim 15^{\circ} \mathrm{C}$ in October to $\sim 4^{\circ} \mathrm{C}$ in January (Table 1). On day 11, water flow suddenly increased from 1.2 to $90.4 \mathrm{~L} / \mathrm{s}$ as a result of rain, and dissolved $\mathrm{O}_{2}$ content increased and conductivity decreased. Water velocity next to litter bags ranged from 0.01 to $0.64 \mathrm{~m} / \mathrm{s}$. The flood caused significant differences among bags retrieved on consecutive sampling dates (Kruskal-Wallis statistic $=25.86, p<$ $0.005)$, but not among bags retrieved on the same day.

\section{Bacteria and fungi}

Fungi and bacteria accumulated on the leaf material following a logistic pattern (Fig. 1A). However, bacteria began a $2^{\text {nd }}$ increase after day 73 of the experiment, whereas fungi remained stable until the end of the experiment. Fungal biomass was $\sim 200 \times$ higher than bacterial biomass except during week 2 (Fig. 1A).

\section{Microfauna}

The most abundant groups of microfauna were flagellates, testamoebae, and ciliates (Fig. 2A). Microfauna density and biomass increased during week 1 (Fig. 1A) to $1.12 \times 10^{4}$ individuals (ind.) $/ g$ leaf $\mathrm{DM}$ (testamoebae) and $7.3 \times 10^{4}$ ind./g leaf DM (flagellates) (Fig. 2A). Ciliate density was moderate (240$\sim 5000$ ind./g leaf DM), except on day 93 when it peaked at $1.95 \times 10^{4}$ ind./g leaf DM. Microfauna community composition differed among days (ANOSIM, $R=0.52, p=0.001$ ), and these differences were greatest (with dissimilarities $>70 \%$ ) immediately after the flood (day 17; SIMPER), when microfauna density was almost 0 (Fig 2A). Microfauna densities remained low until day 93, when they increased again. On day 93, ciliate density was high, but taxon richness was lower than before day 17. Hypotrichia (UFF) and Hymenostomata (DFF) were the most abundant ciliates from day 93 to day 112, when Pleurostomatida (RF) also were present.

\section{Meiofauna}

Densities of Chironomidae, Rotifera, and Oligochaeta were higher than those of other groups of meiofauna. Community composition differed significantly among sampling days $(R=0.835, p=0.001)$ and between samples collected before and after the flood ( $R=0.73, p=0.001$ ). Microcrustaceans were the most common group of meiofauna only during the $1^{\text {st }}$ week. This group consisted mainly of ostracods and copepods (with more nauplii than copepodites and adults) and, to a lesser extent, cladocerans. Two patterns were observed during colonization (Fig. 2B), corresponding to temporary and permanent meiofauna. Temporary meiofauna, including early larval stages of Chironomidae, Oligochaeta, Plecoptera, and Ephemeroptera (Robertson et al. 2000), followed the dynamics of their macroinvertebrate representatives (Table 2, Fig. 1B) and increased during the late phases of colonization. Densities of permanent meiofauna (Rotifera, Nematoda, Microcrustacea, Microturbellaria, and Tardigrada) were lower than those of temporary meiofauna (Fig. 2B). Permanent meiofauna contributed to total meiofauna density, but most meiofaunal biomass was made up by temporary meiofauna (Fig. 3).

\section{Macroinvertebrates}

Macroinvertebrate densites were low and ranged between 0 and 800 ind./g leaf DM (Fig. 2C). Large 
TABLE 1. Physical and chemical characteristics of Fuirosos stream water during the 4-mo colonization experiment. Values are individual measures of variables on the 11 sampling days.

\begin{tabular}{|c|c|c|c|c|c|}
\hline Day & Temperature $\left({ }^{\circ} \mathrm{C}\right)$ & $\mathrm{O}_{2}(\mathrm{mg} / \mathrm{L})$ & Conductivity $(\mu \mathrm{S} / \mathrm{cm})$ & $\mathrm{pH}$ & Discharge $(\mathrm{L} / \mathrm{s})$ \\
\hline 2 & 12.5 & 6.29 & 305.0 & 6.75 & 4.62 \\
\hline 7 & 15.3 & 5.2 & 302.0 & 6.54 & 1.19 \\
\hline 17 & 12.8 & 10 & 181.8 & 7.00 & 90.41 \\
\hline 28 & 11.8 & 18.1 & 188.0 & 6.64 & 63.97 \\
\hline 73 & 8.5 & 11.20 & 174.3 & 7.79 & 60.10 \\
\hline 93 & 4.3 & 12.64 & 188.6 & 7.73 & 30.23 \\
\hline 112 & 8.2 & 9.55 & 198.2 & 6.82 & 14.00 \\
\hline Mean $\pm 1 \mathrm{SE}$ & $10.8 \pm 0.9$ & $9.59 \pm 1.13$ & $229.81 \pm 18.61$ & $7.02 \pm 0.46$ & $31.39 \pm 31.64$ \\
\hline
\end{tabular}

Ostracoda $(>250 \mu \mathrm{m})$ were the earliest colonizers, followed by Plecoptera (mainly Nemouridae) and Chironomidae (abundant on day 44; Fig. 2C). Ephemeroptera, Oligochaeta, and Coleoptera increased late in the study. Macroinvertebrate biomass increased during colonization, and made up most of the total invertebrate biomass at the end of the study (Fig. 1B).
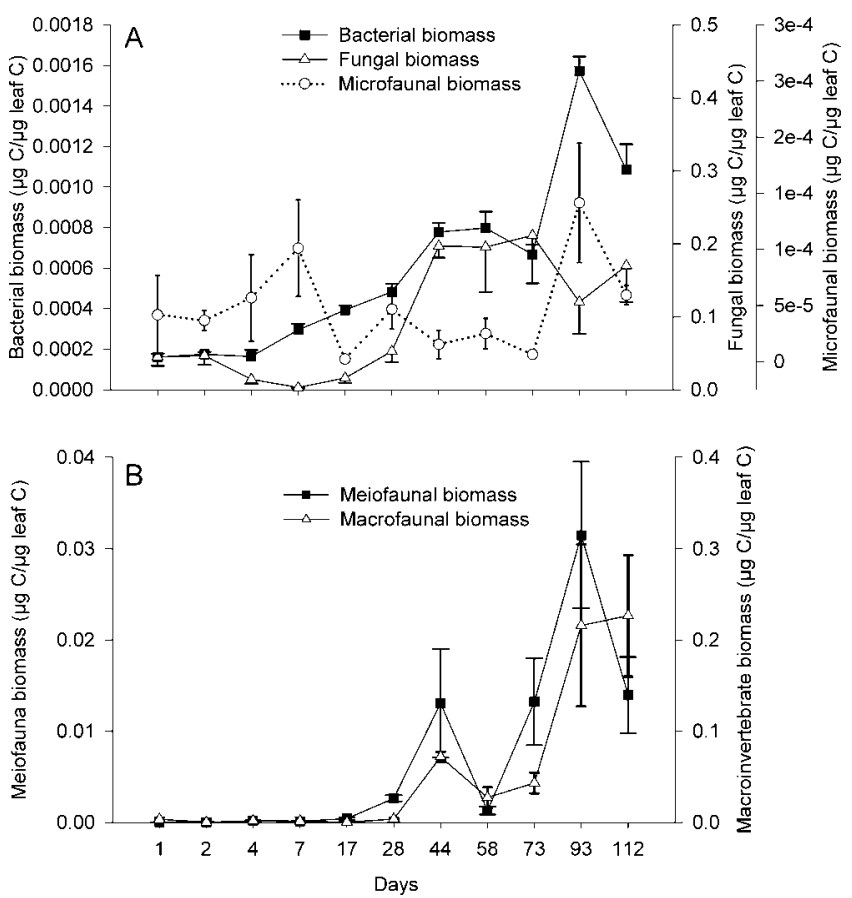

FIG. 1. Mean ( $\pm 1 \mathrm{SE})$ bacterial, fungal, and microfaunal biomass (A) and meiofaunal and macroinvertebrate biomass (B) during a 4-mo study of colonization of leaf litter in Fuirosos. Error bars are as follows: bacteria (positive thick line and long cap), fungi (negative thick line and short cap), microfauna (thin line and short cap), meiofauna (thin line and long cap), and macroinvertebrates (thick line and short cap).
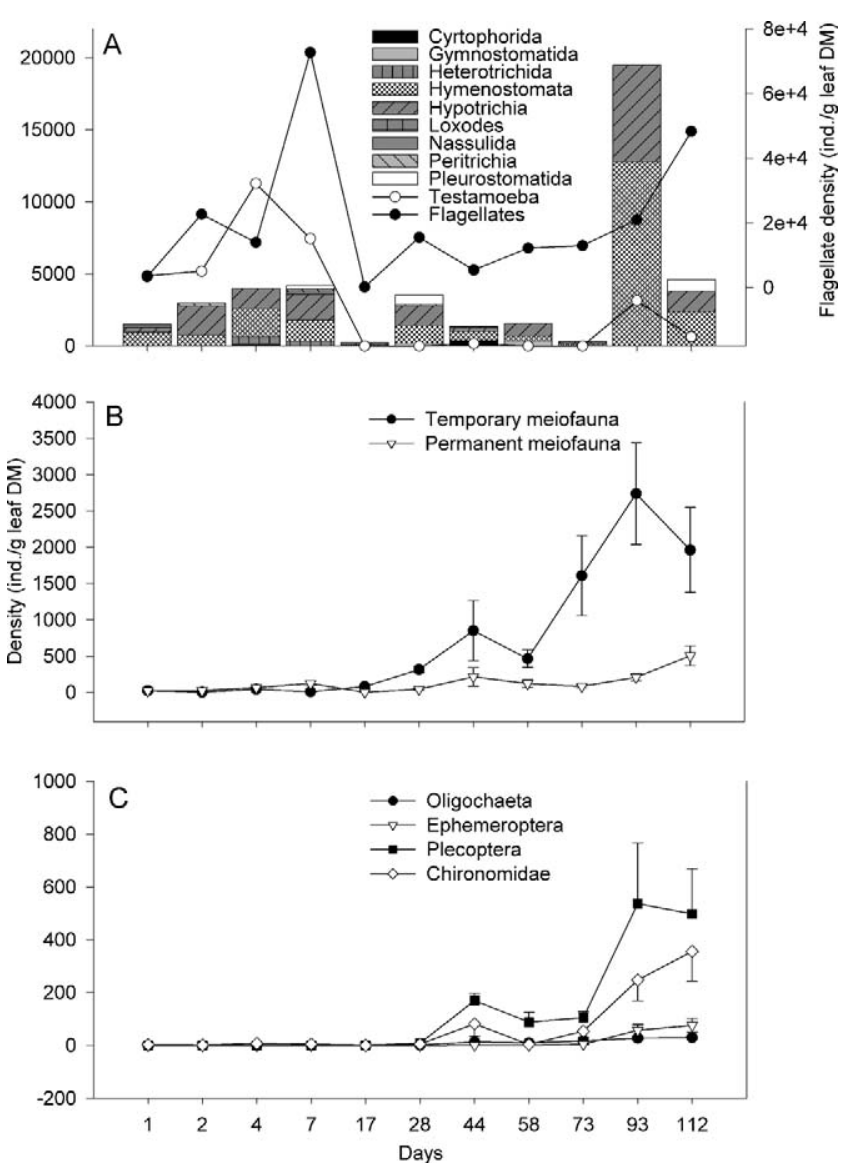

FIG. 2. Mean density of microfauna (A), meiofauna $( \pm 1$ $\mathrm{SE})(B)$, and macroinvertebrates $( \pm 1 \mathrm{SE})(\mathrm{C})$ during a 4-mo study of colonization of leaf litter in Fuirosos. In panel A, densities of ciliates and Testamoebae are shown on $y$-axis 1 and densities of flagellates are shown on $y$-axis 2 . In panels $B$ and $C$ error bars are as follows: temporary and permanent meiofauna, Oligochaeta, and Ephemeroptera (normal line and cap); Plecoptera (positive cap); and Chironomidade (negative cap). DM = dry mass. 
TABLE 2. Spearman's rank correlation coefficients $(r)$ between biomasses of macroinvertebrates and their meiofaunal-sized representatives (temporary meiofauna) across all sampling days. ${ }^{*} p<0.05$ (with false discovery rate correction).

\begin{tabular}{lc}
\hline Taxon & $R$ \\
\hline Coleoptera & $0.92^{*}$ \\
Oligochaeta & $0.95^{*}$ \\
Chironomidae & $0.75^{*}$ \\
Ephemeroptera & $0.94^{*}$ \\
Plecoptera & $0.80^{*}$ \\
\hline
\end{tabular}

Relationships between organisms and environmental characteristics

Microcrustacean biomass and conductivity were significantly negatively correlated with discharge (Table 3). Some ciliates also tended to be negatively correlated with discharge, but these relationships were not statistically significant after FDR correction. Oligochaeta, Chironomidae, Plecoptera, and Ephemeroptera biomasses were significantly positively correlated with bacterial biomass and negatively correlated with water temperature. Fungal biomass was significantly positively correlated with macroinvertebrate biomass and negatively correlated with water temperature (Table 3).

\section{Allocation of $C$ during the colonization}

Fungal biomass accounted for $\sim 32$ to $\sim 93 \%$ of the total organismal (nonleaf) $\mathrm{C}$ in the litter bags during the experiment, bacterial biomass accounted for $\sim 0.2$ to $\sim 6 \%$, and faunal biomass accounted for $\sim 0.03$ to $\sim 8.4 \%$ (meiofauna) and $\sim 1.7$ to $\sim 58 \%$ (macroinvertebrates) (Table 4). Between days 1 and 7, C exchange between compartments was rapid and shifted from fungal $(\sim 93 \%)$ to bacterial $(\sim 6 \%)$ and faunal (mainly macroinvertebrate) compartments $(\sim 30 \%)$. The flood reset the system and shifted the highest percentage of $\mathrm{C}$ back to the fungal compartment. Fungi continued to have the highest percentage of total $C$ until late in the experiment when macroinvertebrates and, to a lesser extent, temporary meiofauna, made up most of the nonleaf $\mathrm{C}$ in the litter bags. Between days 28 and 58, C in the temporary meiofaunal compartment was transferred to the macroinvertebrate compartment. After the flood, when water temperature was lower and discharge was higher than before the flood, almost 70 $\mathrm{d}$ of colonization were required to attain invertebrate $\mathrm{C}$ biomasses similar to those observed on day 7. On day 93, 60 to $70 \%$ of the total nonleaf $C$ in the litter bags consisted of invertebrate biomass and 30 to $40 \%$ corresponded to fungal biomass.

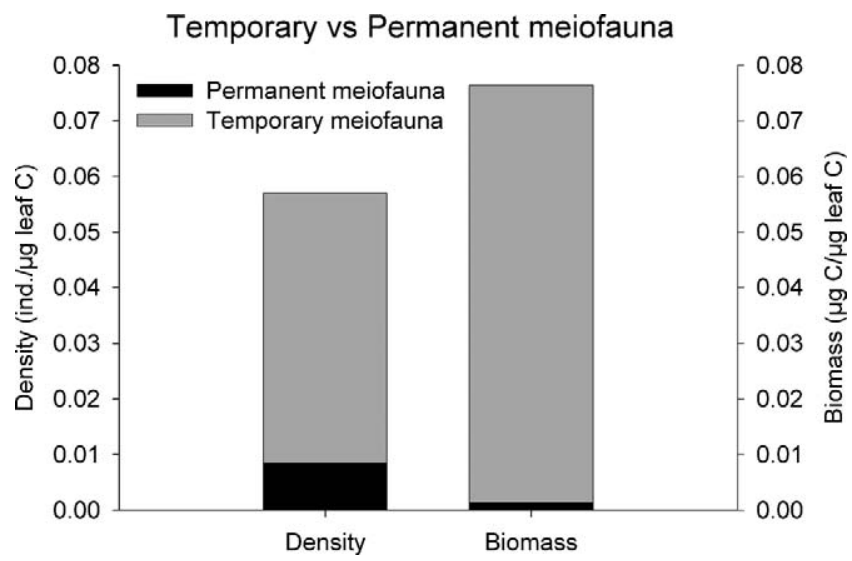

FIG. 3. Contribution of temporary and permanent meiofauna to total meiofaunal density and biomass. Both meiofaunal density and biomass are relative to leaf $\mathrm{C}$ biomass.

\section{Discussion}

\section{Factors affecting colonization dynamics}

Flow and temperature influence leaf litter breakdown. In desert streams, the duration of flood-free periods is an important factor regulating community biomass and efficiency (Grimm and Fisher 1989). In Mediterranean streams, low rainfall and high temperatures in summer cause early leaf fall in riparian forests (Acuña et al. 2004). Vázquez et al. (2007) reported an increase of dissolved organic $C$ when flow resumed because of the partly decomposed leaves that had accumulated in the stream bed. Therefore, this accumulated organic $C$ is available as a source of energy and shelter to aquatic organisms. Mechanical breakdown caused by the turbulent waters when flows resume provides more surface area for colonization, accelerates decomposition of leaf litter, and enhances its conditioning (Heard et al. 1999, Graça 2001). A similar process occurs in semiarid Australian rivers (Francis and Sheldon 2002).

In Fuirosos, biological succession on decaying leaf litter was strongly correlated with discharge and water temperature. Our study began shortly before a flood associated with the end of the summer drought. Fine particulate OM (FPOM) accumulation and rapid primary colonization occurred during the initial period of low discharge and moderate water temperature. During the flood, the FPOM drifted downstream. After the flood, Populus leaves broke apart and were almost entirely washed out of the mesh bags by day 58; Platanus leaves, though broken, remained in the bags. The flood reset the colonization process. Subsequent recolonization occurred under higher flow, cooler temperatures, and different leaf characteristics, and 
TABLE 3. Spearman's rank correlation coefficients $(r)$ test among protozoans (feeding types, see text), groups of metazoans, fungi, bacteria, and environmental variables. $\mathrm{TM}=$ temporary meiofauna size representatives of a macroinvertebrate group, PM $=$ permanent meiofauna, $\mathrm{DO}=$ dissolved $\mathrm{O}_{2}, \mathrm{UFF}=$ upstream filter feeders (ciliate feeding group). ${ }^{*} p<0.05$ but does not meet the False Discovery Rate (FDR) cutoff, ${ }^{* *} p<0.05$ (corrected by FDR).

\begin{tabular}{|c|c|c|c|c|}
\hline Variable & Fungi & Bacteria & Temperature & Discharge \\
\hline Chironomidae & $0.62^{*}$ & $0.81^{* *}$ & $-0.75^{* *}$ & -0.03 \\
\hline Ephemeroptera & $0.76^{* *}$ & $0.88^{* *}$ & $-0.90^{* *}$ & 0.24 \\
\hline Gastropoda & $0.74^{* *}$ & $0.83^{* *}$ & $-0.87^{* *}$ & 0.13 \\
\hline Microcrustacea (PM) & $-0.62^{*}$ & -0.58 & 0.49 & $-0.87^{* *}$ \\
\hline Plecoptera (TM) & $0.90^{* *}$ & $0.77^{* *}$ & $-0.72^{* *}$ & 0.53 \\
\hline Plecoptera & $0.75^{* *}$ & $0.92^{* *}$ & $-0.88^{* *}$ & 0.49 \\
\hline Rotifera (PM) & $0.66^{*}$ & $0.83^{* *}$ & $-0.73^{* *}$ & 0.02 \\
\hline Fungi & - & $0.67^{*}$ & $-0.83^{* *}$ & 0.48 \\
\hline Bacteria & $0.67^{*}$ & - & $-0.76^{* *}$ & 0.44 \\
\hline UFF ciliates & -0.38 & 0.04 & 0.09 & $-0.62^{*}$ \\
\hline $\mathrm{DO}$ & $0.62^{*}$ & $0.62^{*}$ & -0.60 & $0.88^{* *}$ \\
\hline
\end{tabular}

these changes were associated with shifts in the composition of the colonizing community and slower transfer of $\mathrm{C}$ between compartments.

\section{Settlement sequence of colonizers}

Our choice of mesh size for the litter bags allowed us to study colonization of leaf litter by micro- and meiofauna, but also might have favored accumulation of detritus and its associated fauna. A procedural control might have permitted us to correct for litterbag effects (Boulton and Boon 1991). However, Acuña et al. (2005) surveyed naturally deposited leaves in Fuirosos and reported similar invertebrate composition and densities of the same order of magnitude as those in our litter bags on days 2 and 4 .

Hydrological stability (discharge between 1-5 L/s, water velocities $<12 \mathrm{~cm} / \mathrm{s}$ ) and high water tempera- tures allowed initial colonization of litter bags by microfauna, which achieved maximum diversity in this period. UFF and DFF feeding types appeared during this early stage of colonization. Both groups have membranelles that allow them to capture small particles (DFF: $<2 \mu \mathrm{m}$, UFF: $\sim 2 \mu \mathrm{m}$ ), such as bacteria and flagellates, that were abundant in this period. However, microfaunal densities were much lower than those reported on decomposing leaves in temperate streams (Bott and Kaplan 1989, Schönborn 1982) or in sandy sediments in Fuirosos (Domènech et al. 2006).

During week 1, FPOM retained by the litter bags was colonized quickly by meiofauna. Microcrustaceans thrived in these conditions because of their feeding preference for FPOM-associated microflora (Perlmutter and Meyer 1991) and the shelter provided by the clumps of FPOM (Robertson and Milner 2001, Gaudes et al. 2006). Clumps of FPOM also facilitate

TABLE 4. Percentages of total organismal $\mathrm{C}$ in each group of organisms that colonized leaf litter bags during a 4-mo experiment. Total absolute $\mathrm{C}$ is expressed as mg organismal $\mathrm{C} /$ litter bag.

\begin{tabular}{|c|c|c|c|c|c|c|c|}
\hline $\begin{array}{l}\text { Sampling } \\
\text { day }\end{array}$ & \multicolumn{6}{|c|}{$\%$ total C } & $\begin{array}{c}\text { Total } \\
\text { organismal C }\end{array}$ \\
\hline 1 & 92.68 & 0.33 & 0.09 & 0.03 & 0.03 & 6.84 & 142.95 \\
\hline 7 & 59.80 & 6.18 & 2.11 & 1.87 & 0.58 & 29.46 & 13.29 \\
\hline 17 & 93.65 & 2.29 & 0.01 & 0.02 & 2.35 & 1.68 & 65.61 \\
\hline 28 & 88.64 & 0.81 & 0.08 & 0.10 & 4.33 & 6.03 & 184.63 \\
\hline 112 & 41.28 & 0.26 & 0.01 & 0.11 & 3.28 & 55.05 & 127.71 \\
\hline
\end{tabular}


recolonization of downstream substrata during high flow events because they are retained in woody debris, leaf packs, and shores of the stream following high flow events.

After the flood, litter bags were progressively colonized by shredders and collector-gatherers (achieving the $60 \%$ of total $\mathrm{C}$ on day 93). Leaves trap FPOM (Richardson 1992), which increases their nutritional value to collector-gatherers (Gjerlov and Richardson 2004, Scealy et al. 2007). After 1 mo of colonization, the density of temporary meiofauna also increased, probably as a result of the greater microbial biomass in the remaining leaf material (Palmer et al. 2000).

\section{Contribution to C budget and microbial loop}

Our study shows changes in $\mathrm{C}$ allocation between compartments during the leaf colonization related to hydrology, temperature, and organismal dynamics. Before the flood, nearly $40 \%$ of the total organismal C in the litter bags was in the bacterial and faunal compartments. After the flood, $\mathrm{C}$ in the faunal compartments was carried downstream, and fungi had the highest biomass. Late in the colonization, fauna became more abundant again, and transfer of $C$ from the temporary meiofauna to the macroinvertebrate compartment was observed as a consequence of organismal growth.

Meiofauna can consume $22 \%$ of daily bacterial C production (Perlmutter and Meyer 1991). Meiofauna and macroinvertebrates differ in their consumption of bacterial C (Perlmutter and Meyer 1991). Meiofauna apparently prefer detritus-associated microflora, whereas macroinvertebrates nonselectively ingest large amounts of detritus. Competition between macroinvertebrates and meiofauna for bacterial C (Swan and Palmer 2000) and competition between the 2 major decomposers, macroinvertebrates and fungi, for leaf-tissue compounds (Gessner et al. 1999) are important, but underresearched, phenomena. Knowledge of the manipulation, processing, and consumption of organic matter by all groups involved will contribute to a better understanding of the decomposition process.

\section{Concluding remarks}

Our results indicate that colonization of decaying leaf material is highly dependent on hydrology and temperature. In Mediterranean forested streams, the occurrence of floods during organic matter accumulation in the streambed could shape the colonization (and subsequent decomposition) process and be essential to ecosystem functioning. After the flood, almost $70 \mathrm{~d}$ were necessary to restore the $\mathrm{C}$ budget values in the different compartments to those achieved during the first $10 \mathrm{~d}$ of colonization. The Mediterranean region is expected to endure higher temperatures and lower precipitation, especially in summer, under predicted climatic changes (IPCC 2007). Under these conditions, the quantity of leaves in the streambed could increase, as happens now in the driest years (Sabater et al. 2001, Acuña et al. 2005), and colonization and decomposition dynamics might be accelerated with the first autumn rains. Changes in patterns of precipitation could alter the duration, frequency, and magnitude of flow and flood pulses. Modification of the inundation regime is expected to decelerate breakdown rates and reduce breakdown heterogeneity-and both factors influence the decomposition process (Langhans and Tockner 2006). The influence of these changes (temperature and flow) on the C budget during leaf-litter processing in the Mediterranean headwater streams remains to be seen.

\section{Acknowledgements}

This research was funded by the Spanish Ministry of Education and Science project CGL2005-06739-C0201/02 and by the Fundación Banco Bilbao Vizcaya Argentaria project GLOBRIO. We thank L. Cardador and $\mathrm{H}$. Salvadó for their assistance and assessment during sample processing, and A. Boulton and 2 anonymous referees for helpful comments on our manuscript.

\section{Literature Cited}

Acuña, V., A. Giorgi, I. Muñoz, F. Sabater, and S. Sabater. 2007. Meteorological and riparian influences on organic matter dynamics in a forested Mediterranean stream. Journal of the North American Benthological Society 26: 54-69.

Acuña, V., A. Giorgi, I. Muñoz, U. Uehlinger, and S. Sabater. 2004. Flow extremes and benthic organic matter shape the metabolism of a headwater Mediterranean stream. Freshwater Biology 49:1-12.

Acuña, V., I. Muñoz, A. Giorgi, M. Omella, F. SAbater, and S. SABATER. 2005. Drought and postdrought recovery cycles in an intermittent Mediterranean stream: structural and functional aspects. Journal of the North American Benthological Society 24:919-933.

Allan, J. D. 1995. Stream ecology: structure and function of running waters. Chapman and Hall, London, UK.

ANDRASSY, I. 1956. Die rauminhalts- und gewichtsbestimmung der fadenwürmer (Nematoden). Acta Zoologica Academiae Scientiarum Hungaricae 2:1-15.

BALDY, V., AND M. O. GESSNER. 1997. Towards a budget of leaf litter decomposition in a first-order woodland stream. Comptes Rendus de l'Academie des Sciences, Serie III. Sciences de la Vie/Life Sciences 320:747-758. 
Baldy, V., M. O. Gessner, And E. Chauvet. 1995. Bacteria and fungi breakdown of leaf litter in a large river. Oikos 74: 93-102.

Bärlocher, F., C. Canhoto, and M. A. S. Graça. 1995. Fungal colonisation of alder and eucalypt leaves in two streams in central Portugal. Archiv für Hydrobiologie 133:57-68.

Benjamini, Y., And Y. Hochberg. 1995. Controlling the false discovery rate: a practical and powerful approach to multiple testing. Journal of the Royal Statistical Society: Series B Statistical Methodology 57:289-300.

Benke, A. C., A. D. Huryn, L. A. Smock, and J. B. Wallace. 1999. Length-mass relationships for freshwater macroinvertebrates in North America with particular reference to the southeastern United States. Journal of the North American Benthological Society 18:308-343.

BorChARDT, M. A., AND T. L. BOTT. 1995. Meiofaunal grazing of bacteria and algae in a Piedmont stream. Journal of the North American Benthological Society 14:278-298.

BotT, T. L., AND M. A. BORChARDT. 1999. Grazing of protozoa, bacteria, and diatoms by meiofauna in lotic epibenthic communities. Journal of the North American Benthological Society 18:499-513.

BotT, T. L., AND L. A. Kaplan. 1989. Densities of benthic protozoa and nematodes in a Piedmont stream. Journal of the North American Benthological Society 8:187-196.

Bottrell, H. H., A. Duncan, Z. M. Gliwicz, E. Grygierek, A. Herzig, A. Hillbricht-Ilkowska, H. Kurasawa, P. Larsson, AND T. WeglensKa. 1976. A review of some problems in zooplankton production studies. Norwegian Journal of Zoology 24:419-456.

Boulton, A. J., AND P. I. Boon. 1991. A review of methodology used to measure leaf litter decomposition in lotic environments: time to turn over an old leaf? Australian Journal of Marine and Freshwater Research 42:1-43.

BRAtBAK, G., AND I. Dundas. 1984. Bacterial dry matter content and biomass estimations. Applied and Environmental Microbiology 48:755-757.

DomènECH, R., A. GAudes, J. C. López-Doval, H. SAlvadó, AND I. MuÑOZ. 2006. Effects of short-term nutrient addition on microfauna density in a Mediterranean stream. Hydrobiologia 568:207-215.

Fenchel, T. 1986. Protozoan filter feeding. Progress in Protistology 1:65-113.

Fenchel, T. 1987. Ecology of protozoa. Science Technical Publishers, Madison, Wisconsin.

Findlay, S. E. G., J. Tank, S. Dye, H. M. Valett, P. J. Mulholland, W. H. McDowell, S. L. Johnson, S. K. Hamilton, J. Edmonds, W. K. Dodds, and W. B. Bowden. 2002. A cross-system comparison of bacterial and fungal biomass in detritus pools of headwater streams. Microbial Ecology 43:55-66.

FisHER, S. G., AND G. E. LiKENS. 1973. Energy flow in Bear Brook, New Hampshire: an integrative approach to stream ecosystem metabolism. Ecological Monographs 43:421-439.

Foissner, W., AND H. Berger. 1996. A user-friendly guide to the ciliates (Protozoa, Ciliophora) commonly used by hydrobiologists as bioindicators in rivers, lakes and waste waters, with notes on their ecology. Freshwater Biology 35:375-482.

FrANCIS, C., AND F. SHELdON. 2002. River Red Gum (Eucalyptus camaldulensis Dehnh.) organic matter as a carbon source in the lower Darling River, Australia. Hydrobiologia 481: 113-124.

Franco, C., G. F. Esteban, and C. Téllez. 1998. Colonization and succession of ciliated protozoa associated with submerged leaves in a river. Limnologica 28:275-283.

GAsith, A., AND V. H. Resh. 1999. Streams in Mediterranean climate regions: abiotic influences and biotic responses to predictable seasonal events. Annual Review of Ecology and Systematics 30:51-81.

Gaudes, A., S. Sabater, E. Vilalta, and I. Muñoz. 2006. The nematode community in cyanobacterial biofilms in the river Llobregat, Spain. Nematology 8:909-919.

Gessner, M. O. 1997. Fungal biomass, production and sporulation associated with particulate organic matter in streams. Limnetica 13:33-44.

Gessner, M. O., AND E. Chauvet. 1993. Ergosterol-to-biomass conversion factors for aquatic hyphomycetes. Applied and Environmental Microbiology 59:502-507.

Gessner, M. O., E. Chauvet, and M. Dobson. 1999. A perspective on leaf litter breakdown in streams. Oikos 85:377-383.

Gessner, M. O., AND A. L. Schmitt. 1996. Use of solid-phase extraction to determine ergosterol concentrations in plant tissue colonized by fungi. Applied and Environmental Microbiology 62:415-419.

GJERLOV, C., AND J. S. RichaRdSON. 2004. Patchy resources in a heterogeneous environment: effects of litter and forest cover on colonization patterns of invertebrates in a British Columbian stream. Archiv für Hydrobiologie 161: 307-327.

GodshalK, G. L., AND R. G. Wetzel. 1978. Decomposition of aquatic angiosperms. I. Dissolved components. Aquatic Botany 5:281-300.

Gordon, N. D., T. A. McMahon, And B. L. Finlayson. 1992. Stream hydrology. An introduction for ecologists. $2^{\text {nd }}$ edition. Wiley, Chichester, UK.

GraçA, M. A. S. 2001. The role of invertebrates on leaf litter decomposition in streams - a review. International Review of Hydrobiology 86:383-393.

GraçA, M. A. S., AND C. CANHOto. 2006. Leaf litter processing in low order streams. Limnetica 25:1-10.

Grimm, N. B., AND S. G. FISHER. 1989. Stability of periphyton and macroinvertebrates to disturbance by flash floods in a desert stream. Journal of the North American Benthological Society 8:293-307.

Gulis, V., AND K. SubERKROPP. 2003. Interactions between stream fungi and bacteria associated with decomposing leaf litter at different levels of nutrient availability. Aquatic Microbial Ecology 30:149-157.

Heard, S. B., G. A. Schultz, C. B. Ogden, and T. C. Griesel. 1999. Mechanical abrasion and organic matter processing in an Iowa stream. Hydrobiologia 400:179-186.

Hieber, M., AND M. O. GeSSNER. 2002. Contribution of stream detritivores, fungi, and bacteria to leaf breakdown based on biomass estimates. Ecology 83:1026-1038. 
iPCC (Intergovernmental Panel for Climate Change). 2007. Summary for policymakers in S. Solomon, D. Qin, M. Manning, Z. Chen, M. Marquis, K. B. Averyt, M. Tignor, and H. L. Miller (editors). Climate change 2007: the physical science basis. Contribution of working group I to the fourth assessment report of the intergovernmental panel on climate change. Cambridge University Press, Cambridge, UK. (Available from: http://www.ipcc.ch/ pdf/assessment-report/ar4/wg1/ar4-wg1-spm.pdf.)

LAnghans, S. D., AND K. Tockner. 2006. The role of timing, duration, and frequency of inundation in controlling leaf litter decomposition in a river-floodplain ecosystem (Tagliamento, northeastern Italy). Oecologia (Berlin) 147:501-509.

Meyer, E. 1989. The relationship between body length parameters and dry mass in running water invertebrates. Archiv für Hydrobiologie 117:191-203.

MeYer, J. L. 1994. The microbial loop in flowing waters. Microbial Ecology 28:195-199.

Minshall, G. W., K. W. Cummins, R. C. Petersen, C. E. Cushing, D. A. Bruns, J. R. Sedell, and R. L. Vannote. 1985. Developments in stream ecosystem theory. Canadian Journal of Fisheries and Aquatic Sciences 42:10451055.

Palmer, M. A., C. M. Swan, K. Nelson, P. Silver, and R. AlveSTAD. 2000. Streambed landscapes: evidence that stream invertebrates respond to the type and spatial arrangement of patches. Landscape Ecology 15:565-578.

Pascoal, C., AND F. CAssio. 2004. Contribution of fungi and bacteria to leaf litter decomposition in a polluted river. Applied and Environmental Microbiology 70:5266-5273.

Perlmutter, D. G., And J. L. Meyer. 1991. The impact of a stream-dwelling harpacticoid copepod upon detritally associated bacteria. Ecology 72:2170-2180.

Ramsay, P. M., S. D. Rundle, M. J. Attrill, M. G. Uttley, P. R. Williams, P. S. Elsmere, and A. Abada. 1997. A rapid method for estimating biomass size spectra of benthic metazoan communities. Canadian Journal of Fisheries and Aquatic Sciences 54:1716-1724.

Richardson, J. S. 1992. Food, microhabitat or both? Macroinvertebrate use of leaf accumulations in a montane stream. Freshwater Biology 27:169-176.

Robertson, A. L., AND A. M. MiLnER. 2001. Coarse particulate organic matter: a habitat or a food resource for the meiofaunal community of a recently formed stream? Archiv für Hydrobiologie 152:529-541.

Robertson, A. L., S. D. Rundle, and J. Schmid-Araya. 2000. Putting the meio- into stream ecology: current findings and future directions for lotic meiofaunal research. Freshwater Biology 44:177-183.

Romaní, A. M., A. Giorgi, V. Acuña, And S. Sabater. 2004. The influence of substratum type and nutrient supply on biofilm organic matter utilization in streams. Limnology and Oceanography 49:1713-1721.

Sabater, S., S. Bernal, A. Butturini, E. Nin, and F. Sabater. 2001. Wood and leaf debris input in a Mediterranean stream: the influence of riparian vegetation. Archiv für Hydrobiologie 153:91-102.

Scealy, J. A., S. J. MikA, And A. J. Boulton. 2007. Aquatic macroinvertebrate communities on wood in an Australian lowland river: experimental assessment of the interactions of habitat, substrate complexity and retained organic matter. Marine and Freshwater Research 58:153165.

SCHÖNBORN, W. 1982. Die Ziliatenproduktion in der mittleren Saale. Limnologica 14:329-346.

Slansky, F., AND J. M. Scriber. 1985. Food consumption and utilisation. Pages 87-136 in G. A. Kerkut and L. I. Gilbert (editors). Comprehensive insect physiology. Volume 4. Pergamon Press, Oxford, UK.

Smit, H., E. D. VAnHEel, And S. Wiersma. 1993. Biovolume as a tool in biomass determination of Oligochaeta and Chironomidae. Freshwater Biology 29:37-46.

Swan, C. M., AND M. A. PALMER. 2000. What drives small-scale spatial patterns in lotic meiofauna communities? Freshwater Biology 44:109-122.

VÁzquez, E., A. M. Romaní, F. SABAter, And A. Butturini. 2007. Effects of the dry-wet hydrological shift on dissolved organic carbon dynamics and fate across stream-riparian interface in a Mediterranean catchment. Ecosystems 10: 239-251.

WATERS, T. F. 1977. Secondary production in inland waters. Advances in Ecological Research 10:91-164.

Webster, J. R., AND E. F. Benfield. 1986. Vascular plant breakdown in freshwater ecosystem. Annual Review of Ecology and Systematics 17:567-594.

Received: 17 October 2007 Accepted: 25 July 2008 